\title{
Evaluation of Long-term Intensive Care Patients in a Cardiac Surgery Center
}

\section{Kalp Cerrahisi Merkezinde Uzayan Yoğun Bakım Hastalarının Değerlendirilmesi}

\section{(D) Bedih Balkan1, (D Hatice Dilek Özcanoğlu²}

1İstanbul Provincial Directorate of Health, Mehmet Akif Ersoy Chest and Cardiovascular Diseases Hospital, Clinic of Intensitive Care Unit, İstanbul, Turkey

2İstanbul Provincial Directorate of Health, Mehmet Akif Ersoy Chest and Cardiovascular Diseases Hospital, Clinic of Anesthesiology, İstanbul, Turkey

\section{Abstract}

Objective: This study was aimed to evaluate the clinical and demographic characteristics of patients in a chronic intensive care unit (ICU) in a cardiac surgery center and to research the effect of these characteristics on scoring systems used.

Method: From 1 September 2014 to 1 September 2019, the study was performed retrospectively with cases admitted to the chronic ICU due to lengthened intensive care requirements after monitoring in the cardiovascular surgery intensive care or coronary ICU. Each case had study forms including information like age, gender, comorbid diseases, acute physiology and chronic health evaluation 2 (APACHE 2) scores, Glasgow Coma scale, the results were statistically assessed.

Results: Two hundred and sixty three patients were enrolled for this study. The mean age of patients was $64.6 \pm 6$ years, with $61 \%$ male and $39 \%$ female. Of cases, $46 \%$ had coronary bypass surgery $(n=122), 25 \%$ had valve + aorta dissection ( $n=67), 19 \%$ had acute coronary artery $(n=51)$ and $7 \%$ had peripheral artery disease $(n=17)$. The mean follow-up duration for patients was identified as $44.2 \pm 96.38$ days. Cases developing mortality had significantly higher APACHE 2 scores compared to cases without mortality $(p<0.05,24.9 \pm 8.0$ vs $20.5 \pm 7.2)$. The most common comorbidities in cases were kidney failure in $41 \%(n=48)$. Sixty-nine cases had a percutaneous tracheostomy and 21 cases had a surgical tracheostomy, for a total of 90 cases with a tracheostomy.

The mortality rate of entire monitored patients during this study period was $42.6 \%$.

Conclusion: Very different problems may be encountered in cases observed in the chronic ICU. For these cases, kidney failure is the most

\section{Öz}

\begin{abstract}
Amaç: $\mathrm{Bu}$ çalışmada kalp cerrahisi merkezinde, kronik yoğun bakım ünitesinde yatan hastaların klinik ve demografik özelliklerinin değerlendirilmesi ve bu özelliklerin kullanılan skorlama sistemlerine olan etkisinin araştırılması amaçlandı.
\end{abstract}

Yöntem: 1 Eylül 2014-1 Eylül 2019 tarihleri arasında retrospektif olarak kardiyovasküler cerrahi yoğun bakım veya koroner yoğun bakım ünitesinde izlenip yoğun bakım sürecinin uzaması nedeniyle kronik yoğun bakım ünitesine alınan olgularda gerçekleştirildi. Her bir olgunun yaş, cinsiyet, eşlik eden hastalık, Akut Fizyoloji ve Kronik Sağılı Değerlendirmesi 2 (APACHE 2) skorları, Glasgow Koma skalası, bilgileri içeren çalışma formu oluşturuldu. Sonuçlar istatistiksel olarak değerlendirildi.

Bulgular: İki yüz altmış üç hasta çalışmaya alınmıştır. Hastaların ortalama yaşları $64,6 \pm 6$ yıl olup, \%61'i erkek \%39'u kadındı. Olguların \%46'una koroner bypass $(n=122)$ cerrahisi, \%25'ine kapak + aort diseksiyonu ( $n=67) \% 19$ akut koroner arter sonrası $(n=51) \% 7$ 'si periferik arter hastalığı $(n=17)$ sonrası izlenmişti. Hastaların takip süresi ortalama 44,2士 96,38 gün olarak saptanmıştı. Mortalite gelişen olgularda, mortalite gelişmeyen olgulara göre APACHE 2 skoru anlamlı olarak daha yüksekti ( $p<0,0524,9 \pm 8,0$ vs $20,5 \pm 7,2)$. Olgularda en sık gözlenen komorbidite \%41 $(n=48)$ Böbrek yetmezliği idi. Altmış dokuz olguya perkutan trakeostomi ve 21 olguya cerrahi trakeostomi olmak üzere 90 olguya trakeostomi açıldı. Toplam izlenen hastaların \%42,6'sı $(n=112)$ kaybedildi.

Sonuç: Kronik yoğun bakımda izlenen olgular çok farklı sorunlarla karşılaşılabilir. Bu olgularda böbrek yetmezliği mortaliteyi ve morbiditeyi artıran en önemli risk faktörüdür. Ayrıca hastalarda APACHE 2 skorlaması

Address for Correspondence: Bedih Balkan, i̇stanbul Provincial Directorate of Health, Mehmet Akif Ersoy Chest and Cardiovascular Diseases Hospital, Intensitive Care Unit, İstanbul, Turkey

E-mail: drbedihbalkan21@gmail.com ORCID: orcid.org/0000-0003-3510-6991 Received: 30.11.2019 Accepted: 28.12.2019

Cite this article as: Balkan B, Özcanoğlu HD. Evaluation of Long-term Intensive Care Patients in a Cardiac Surgery Center. Bagcilar Med Bull 2020;5(1):13-20

${ }^{\circ}$ Copyright 2020 by the Health Sciences University, Bagcilar Training and Research Hospital Bagcilar Medical Bulletin published by Galenos Publishing House. 


\section{Abstract}

important risk fact increasing mortality and morbidity. Additionally, APACHE 2 scoring of patients may be helpful for the assessment and prediction of operative mortality and morbidity.

Keywords: Chronic intensive care, cardiac center, APACHE 2, prolonged mechanic ventilation

\section{Öz}

operatif mortalite ve morbiditeyi değerlendirmede ve öngörmede yardımcı olabilir.

Anahtar kelimeler: Uzayan yoğun bakım hastaları, kalp merkezi, APACHE 2, uzamış mekanik ventilasyon

\section{Introduction}

Currently, with the development of technology in cardiac centers, both invasive cardiac procedures and open heart surgery operations are successfully performed for geriatric cases with higher risks. This situation has led to longer intensive care and hospital stays. Studies have stated that nearly $19-45 \%$ of cases have lengthened intensive care duration after open-heart surgery $(1,2)$. For lengthened intensive care duration, a variety of risk factors may be listed such as advanced age, chronic obstructive pulmonary disease (COPD), renal failure or dysfunction, atrial fibrillation, low ejection fraction, emergency surgery, previous history of cardiac surgery and inotrope support (3).

As the intensive care duration lengthens for cases, additional problems that may increase mortality and morbidity may develop and support treatments are required to resolve these problems. The most important of these are tracheostomy performed in cases requiring a longer duration of mechanical ventilation support to reduce complications of endotracheal intubation and mechanical ventilation to a minimum and ensure patient comfort, and renal replacement treatments to control kidney failure.

There are many factors affecting mortality in intensive care units (ICU). By noting these factors, a variety of scoring systems were developed to determine the patient's prognosis. The Acute Physiology and Chronic Health Evaluation (APACHE) is one of the most commonly used systems with this aim. The most important advantages of these scoring systems are the creation of common use, reliable database, lowering costs in intensive care, effective use of resources, assisting in clinical decisions and applications and the opportunity for objective assessment. However, some studies have proposed that these scoring systems are insufficient to estimate the prognosis for patients admitted to intensive care for long durations (4).

Prolonged mechanical ventilation (PMV) is a common problem, with a reported incidence between $2.9 \%$ and $8.6 \%$
(5) after coronary artery bypass grafting (CABG). The PMV patients were older, sicker, had more complex operations and had higher rates of postoperative morbidity.

The primary aim of our study is to investigate the clinical and demographic characteristics of patients admitted to a chronic intensive care center and report our fiveyear experience. Our secondary aim to investigate the correlation of patient APACHE 2 and Glasgow Coma scale (GCS) scores with mortality and our final aim is to evaluate the additional support treatments.

\section{Material and Methods}

This study was retrospectively performed on cases admitted to the chronic ICU due to lengthened intensive care durations in the cardiovascular surgery intensive care or coronary ICU from 1 September 2014 to 1 September 2019. After receiving Ethics Committee permission from the Ethics Committee of İstanbul Provincial Directorate of Health, Mehmet Akif Ersoy Chest and Cardiovascular Diseases Hospital (decision no: 59, date: 10/9/2019), the patient information for patients admitted to chronic intensive care were investigated from admission files and the hospital electronic records system.

Study forms containing information about the age, gender, main diagnosis, intensive care stay duration, problems developing in intensive care, discharge status, etc. of patients were created. Patients with missing information or who stayed in chronic intensive care for less than twentyfour hours were not included in the study.

Additionally, the APACHE 2 and GCS used during the monitoring and treatment of every patient in intensive care were evaluated.

COPD was defined as those patients with a COPD diagnosis or patients who required bronchodilator treatment before surgery. All patients, except for the emergency cases, were examined by the pulmonologist before the operation as a routine workup. 
Chronic renal dysfunction (CRD) denoted the patients who had serum creatinine levels above the normal (0.5-1.3 mg/ dL).

The primary clinical endpoint of this study was to evaluate the weaning failure by 7 days.

Was to evaluate the weaning failure by 7 days after surgery. The pulmonary complication was defined as any pulmonary abnormality occurring in the postoperative period that produces identifiable disease or dysfunction that is clinically significant and that adversely affects clinical course such as Postoperative Respiratory Distress syndrome, reintubation, presence of pneumothorax or pulmonary effusion but not, PMV (6).

The neurologic status of the patients was examined daily: the daily neurologic status of the patients were performed neurologic complication was defined as the presence of any cerebrovascular event or transient neurologic dysfunction.

Infectious complications were defined as positive blood, urine, sputum or wound cultures postoperatively, requiring dressings and intravenous antibiotics, requiring revision surgery (like mediastinal infection) or presence of radiographic infiltrates.

The gastrointestinal complication was defined as the presence of 1 or more of the following (7). Hematemesis or melena (with a $42 \mathrm{~g}$ decrease in hemoglobin level).

\section{Statistical Analysis}

SPSS 22 was used for analyzing data. The distribution of variables was measured with the Kolmogorov-Smirnov test. Descriptive statistics used mean, standard deviation, median, minimum, maximum, frequency and percentage values. Quantitative independent data analysis used the Mann-Whitney U test. Qualitative data analysis used the chi-square test. The effect level was researched with univariate and multivariate logistic regression. $\mathrm{P}<0.05$ was accepted as significant.

\section{Results}

Two hundred sixty three patients ( $61 \%$ male, $39 \%$ female) were enrolled in the study. The mean age of patients was $64.6 \pm 6$ years. Of patients, $61 \%$ were male and $39 \%$ were female. In terms of age, 134 (51\%) were under 65 years and 129 (49\%) were over 65 years of age. The mean duration of stay in intensive care was $34.6 \pm 68$ days. Of cases, $46 \%$ had coronary bypass surgery ( $\mathrm{n}=122), 25 \%$ had valve + aorta dissection $(n=67), 19 \%$ had acute coronary artery $(n=51)$ and $7 \%$ had peripheral artery disease $(n=17)$.
The demographic characteristics of the cases are summarized in Table 1.

The mortality rate of entire monitored patients during this study period was $42.6 \%$ When the reasons for mortality of cases are investigated, the most frequently observe comorbidity was kidney failure at $41 \%(n=48)$. Patients with high APACHE scores and low GCS scores were found and have significantly higher mortality rates.

The mortality status of cases and Influencing factors are summarized in Table 2.

The univariate model observed significant effects of APACHE 2 score, APACHE 2 mortality \% rates, GCS score and renal failure for prediction of mortality $(\mathrm{p}<0.05)$. When the efficacy of these variables was tested in the multivariate model, APACHE 2 expected mortality rate $\%$ and kidney failure were independently significant for prediction of mortality (Table 3). The reasons for which patients were followed up in the ICU (Table 4).

\section{Discussion}

There is limited data related to a long duration of admission to intensive care for patients in Turkey. Agencel et al. (8) reported $9.3 \%$ of patients admitted to a tertiary ICU stayed for 21 days or longer. Martini et al. (9) stated that surgical critical care patients stayed for a mean of 116 days. However, the ICU duration of stay for patients with respiratory diseases was identified as $24.17 \pm 8.38$ days (10). In our study, the surviving group of patients was admitted for $27.5 \pm 33.4$ days, while the patients in the mortality group were monitored in intensive care for mean $44.2 \pm 96.38$ days (Table 1).

As in the whole world, the elderly population is increasing in Turkey. Recent census counts in our country identified the elderly population rate as $8.3 \%$ (11). The elderly population has 4 times higher surgical requirements compared to the remaining population. In the elderly patient group, standard mortality rates for those undergoing operations were identified to be $87 \%$ high compared to unoperated peers compared to data in the national mortality information bank (12). Ursavas et al. (10) in a study of a respiratory ICU did not identify a significant difference between the mean ages of surviving and mortal patients. Similarly, in our study, the mortality rates for patients aged over 65 years, comprising $49 \%$ of the group admitted to intensive care, were not different compared to those under 65 years of age (Table 2). 
According to gender, $60.1 \%$ of our patients were male and $39.9 \%$ were female. Differences linked to gender have been discussed in previous studies; however, it is uncertain whether gender is a predictive factor for clinical outcomes or not. Research in Sweden revealed $60 \%$ of patients in ICU were male; however, disease severity was similar to females (13). Our study shows similarities to this study. In our study, gender was not a factor providing clues about the long duration of stay. It is not considered that gender is associated with high mortality rates (Table 2).

Mortality after cardiac surgery is still a controversial topic in spite of surgical techniques developed and anesthesia management. A variety of studies found mortality after cardiac surgery was from 2.94 to $30.7 \%(14,15)$. In our study, mortality was $42.6 \%$. The reason for this may be linked to the inclusion of those admitted to chronic intensive care after cardiovascular surgery and patients with stay lengthened due to hypoxia or who could not be weaned from mechanical ventilation. Diagnoses for patients admitted to intensive care are various, with some patients having more than one diagnosis. The most common cause in the mortality group was cardiopulmonary arrest occurring due to any factor. In our retrospective study, the patient data not being recorded in detail on admission or cardiopulmonary arrests without explained cause may have led to this general diagnosis being most frequent in the mortality group.

Doerr et al. (16) in a 2801 patient study of APACHE 2 reported it showed good performance in terms of calibration and differentiation statistics. Argyriou et al. (17) reported the APACHE 2 score had a good prediction of outcomes in the cardiac ICU and had comparable differentiative capabilities. Kamış et al. (18) identified the APACHE 2 score for the surviving group in the ICU was $20.5 \pm 7.28$, while it was $24.9 \pm 6.22$ in the mortality group. They reported the

\begin{tabular}{|c|c|c|c|c|c|c|}
\hline & & \multicolumn{2}{|c|}{ Minimum-maximum } & \multirow{2}{*}{$\begin{array}{l}\text { Median } \\
65.0\end{array}$} & \multicolumn{2}{|c|}{$A v . \pm S D / n-\%$} \\
\hline & & 23.0 & 86.0 & & 64.4 & 12.6 \\
\hline \multirow[t]{2}{*}{ Age } & $\leq 65$ & - & - & - & 134 & $51.0 \%$ \\
\hline & $>65$ & - & - & - & 129 & $49.0 \%$ \\
\hline \multirow[t]{2}{*}{ Gender } & Female & - & - & - & 105 & $39.9 \%$ \\
\hline & Male & - & - & - & 158 & $60.1 \%$ \\
\hline Follow-up duration (day) & & 1.0 & 685.0 & 16.0 & 34.6 & 68.4 \\
\hline APACHE 2 & & 7.0 & 50.0 & 22.0 & 22.4 & 7.9 \\
\hline APACHE mortality (\%) & & 8.0 & 97.0 & 42.4 & 44.1 & 22.8 \\
\hline GCS & & 0.0 & 15.0 & 11.0 & 10.5 & 3.9 \\
\hline \multirow[t]{2}{*}{ Valve + Aorta dissection } & $(-)$ & - & - & - & 196 & $74.5 \%$ \\
\hline & $(+)$ & - & - & - & 67 & $25.5 \%$ \\
\hline \multirow[t]{2}{*}{ Bypass } & $(-)$ & - & - & - & 141 & $53.6 \%$ \\
\hline & $(+)$ & - & - & - & 122 & $46.4 \%$ \\
\hline \multirow[t]{2}{*}{ Periphary + carotid + abdominal aneurysm } & $(-)$ & - & - & - & 246 & 93.5\% \\
\hline & $(+)$ & - & - & - & 17 & $6.5 \%$ \\
\hline \multirow[t]{2}{*}{ Coronary + emergency + COPD } & $(-)$ & - & - & - & 212 & $80.6 \%$ \\
\hline & $(+)$ & - & - & - & 51 & $19.4 \%$ \\
\hline \multirow[t]{2}{*}{ Kidney failure } & $(-)$ & - & - & - & 126 & $47.9 \%$ \\
\hline & $(+)$ & - & - & - & 107 & $40.7 \%$ \\
\hline \multirow[t]{2}{*}{ Percutaneous tracheostomy } & $(-)$ & - & - & - & 194 & $73.8 \%$ \\
\hline & $(+)$ & - & - & - & 69 & $26.2 \%$ \\
\hline \multirow[t]{2}{*}{ Surgical tracheostomy } & $(-)$ & - & - & - & 240 & $91.3 \%$ \\
\hline & $(+)$ & - & - & - & 23 & $8.7 \%$ \\
\hline \multirow[t]{2}{*}{ Mortality } & $(-)$ & - & - & - & 151 & $57.4 \%$ \\
\hline & $(+)$ & - & - & - & 112 & $42.6 \%$ \\
\hline
\end{tabular}

GCS: Glasgow Coma scale, COPD: Chronic obstructive pulmonary disease, Av: Average, SD: Standard deviation, APACHE: Acute physiology and chronic health evaluation, n: Number 
APACHE 2 score was significantly higher for patients in the mortality group. In our study, the mean APACHE 2 scores for patients who died were $24.9 \pm 8.0$, while it was $20.5 \pm 7.2$ for surviving patients. Our results are similar to the studies above.

There are a variety of situations limiting the use of another prognostic parameter (19) of the Glasgow Coma scale. Long mechanical ventilation duration and postoperative sedation may be given as examples (20). The values of postoperative scoring systems may be affected by electrolyte and blood glucose imbalance, long mechanical ventilation duration, sedation after open-heart surgery and especially the use of cardiopulmonary bypass (21). As a result, the GCS scoring may not be very effective. In our study, the GCS in the surviving group was $11.4 \pm 3.7$, while it was $9.43 \pm 8$ for the mortality group and this was statistically significant $(\mathrm{p}<0.05)$.
In the postoperative period (22), the use of intra-aortic balloon pumps and ventricular support devices, and Low Cardiac Output syndrome are significant parameters affecting patient outcomes. Unfortunately, most scoring systems ignore these parameters (23). As a result, mortality rates measured with cardiac postoperative scoring systems may be roughly compatible but insufficient. It may be more appropriate to add a cardiac scoring system to the APACHE 2 and GCS scores.

Mortality due to cardiac reasons in CRF patients is reported from $40-50 \%$. This rate is nearly 20 times the risk for people without renal failure (24). Open heart surgery mortality for chronic renal failure (CRF) patients is higher compared to patients with normal kidney functions $(25,26)$. In our study, the renal failure rate was significantly higher in the mortality group compared to the surviving group $(\mathrm{p}<0.05)$ (Table 2).

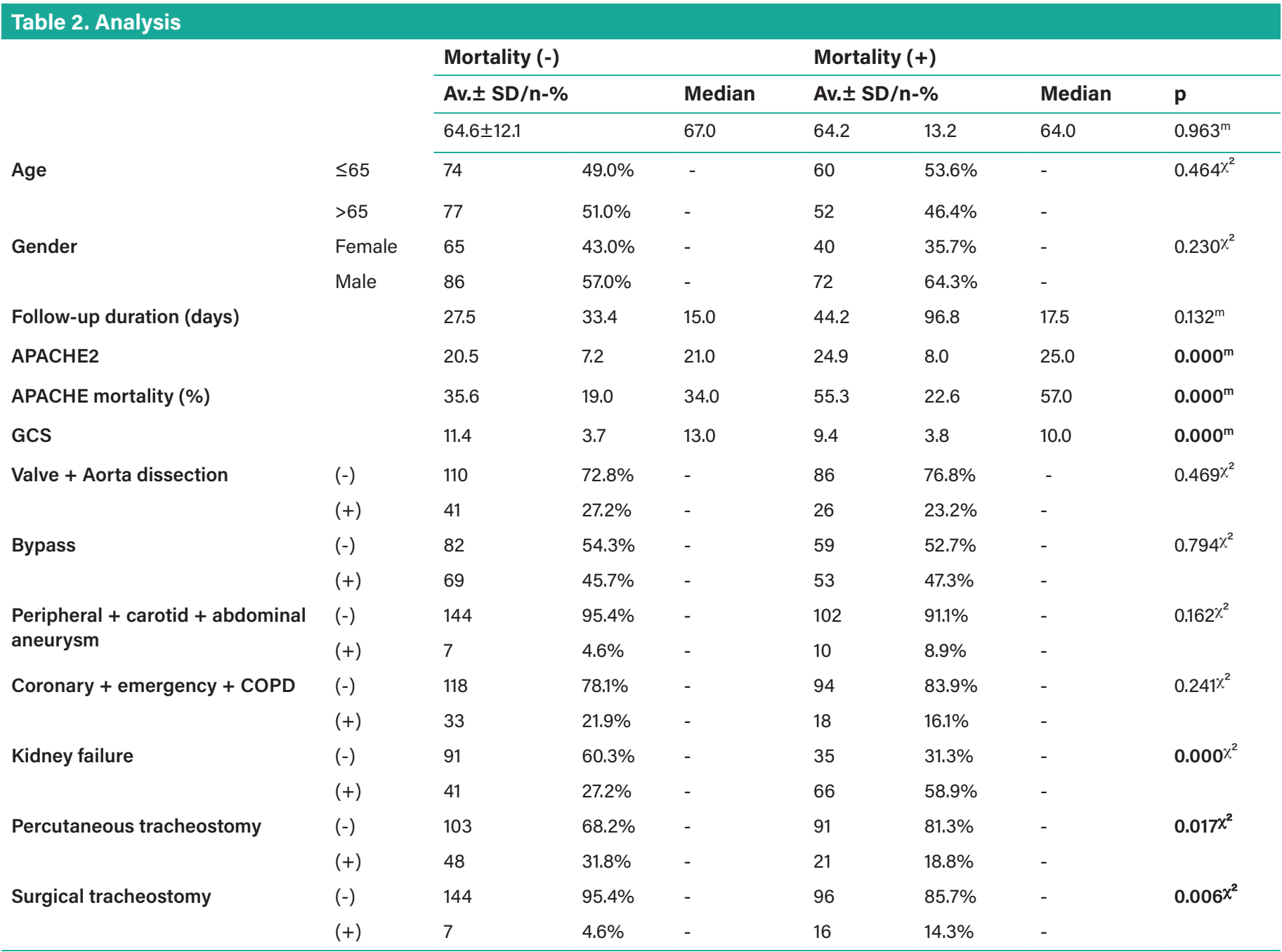

GCS: Glasgow Coma scale, COPD: Chronic Obstructive Oulmonary disease, Av: Average, SD: Standard deviation, APACHE: Acute physiology and chronic health evaluation, n: Number, mMann-Whitney $U$ test $/ \chi^{2}$ : chi-square test 


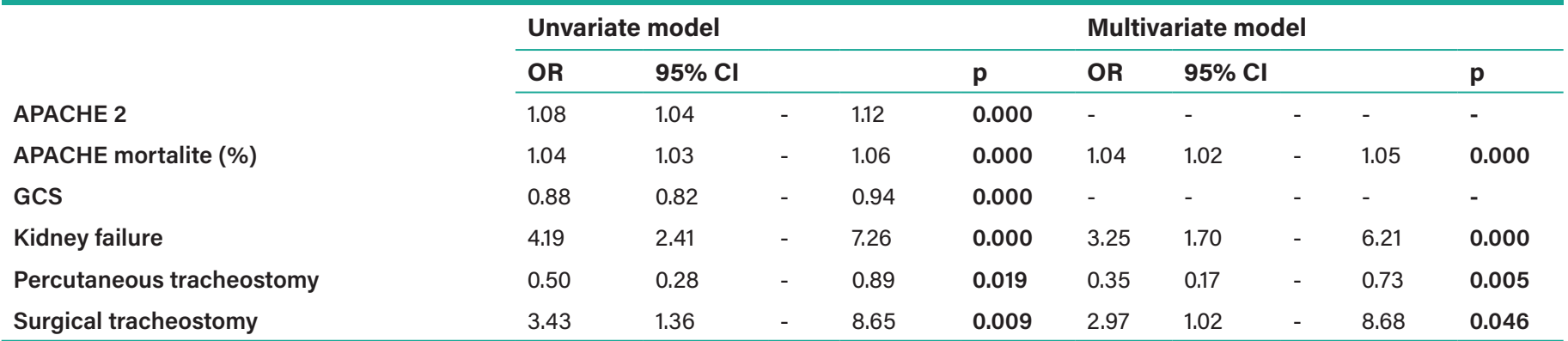

OR: Odds ratio, Cl: Confidence interval, GCS: Glasgow Coma scale, APACHE: Acute physiology and chronic health evaluation

\section{Table 4. Indicators of intensive care}

\begin{tabular}{|c|c|c|}
\hline & $\begin{array}{l}\text { Number of } \\
\text { the patients }\end{array}$ & Percentage \\
\hline Chronic renal failure & 62 & $23.50 \%$ \\
\hline $\begin{array}{l}\text { Chronic obstructive pulmonary } \\
\text { disease }\end{array}$ & 32 & $12.16 \%$ \\
\hline Hypoxic brain injury & 18 & $6.84 \%$ \\
\hline Sepsis & 42 & $15.96 \%$ \\
\hline Mediastinitis & 18 & $6.84 \%$ \\
\hline Advanced right heart failure & 25 & $9.50 \%$ \\
\hline Stroke + subarachnoid hemorrhage & 17 & $6.46 \%$ \\
\hline $\begin{array}{l}\text { Left heart failure + hemodynamic } \\
\text { instability }\end{array}$ & 15 & $5.70 \%$ \\
\hline Gastrointestinal complication & 4 & $1.52 \%$ \\
\hline $\begin{array}{l}\text { Acute Respiratory Distress } \\
\text { syndrome }\end{array}$ & 22 & $8.36 \%$ \\
\hline Peripheral arterial disease & 8 & $3.04 \%$ \\
\hline
\end{tabular}

Tracheostomy is a surgical method frequently applied to patients with long term mechanical ventilation, for treatment of upper respiratory tract obstruction, and those with endotrachealintubationin ICU and predicted to remain linked to a mechanical ventilator for a long period $(27,28)$. Percutaneous tracheostomy (PT) is easily performed, has low complication rates and can be performed in a short period at the patient's bedside so it is mostly chosen in recent years and is frequently used in the ICU for cases with elective tracheostomy especially $(29,30)$. During the PT procedure, complications like hemorrhage, hypoxia, hypercapnia, pneumothorax, pneumomediastinum, subdermal emphysema, paratracheal insertion, tracheal wall injury, aspiration, sudden death, and esophagus injury may be observed (29). In our study, 21 (23\%) surgical tracheostomy and 69 (77\%) PT was performed in 263 patients hospitalized in the ICU in the last 5 years.

In studies, rates for minor hemorrhage linked to the PT procedure are $1.51-5.2 \%(28,31,32)$, while rates for major hemorrhage are $0.75-2.6 \%$ (28). In our study, after the PT procedure, 10 (14.4\%) had minor hemorrhage and two $(1.9 \%)$ had a moderate hemorrhage. For the surgical procedure, 10 (76.8\%) had minor hemorrhage and five (23.8\%) had a moderate hemorrhage. Major hemorrhage was not observed. The reason for the high incidence of minor hemorrhage is considered to be the use of anticoagulant medication by our patients. Only one case developed pneumothorax linked to percutaneous tracheostomy.

Coronary artery bypass surgery comprises a significant portion of everyday cardiac surgery practice; about $90 \%$ for many cardiac surgery centers. PMV is still a significant reason for postoperative morbidity and mortality. Apart from the patient-related suffering, these patients cause a significant increase in the workload of postoperative ICU. Postoperative prolonged ventilation was associated with advanced, CRD, and longer perfusion times in CABG patients (33).

\section{Study Limitations}

There are some limitations to this study. The first is that our study took place in a single-center, so it may not reflect all chronic intensive care patients in Turkey. The second is that it was a retrospective study. There is a need for multicenter studies to further confirm our findings.

\section{Conclusion}

Very different problems may be encountered in cases observed in the chronic ICU. For these cases, kidney failure is the most important risk fact increasing mortality and morbidity. Additionally, APACHE 2 scoring of patients may be helpful for the assessment and prediction of operative mortality and morbidity.

\section{Ethics}

Ethics Committee Approval: Ethics Committee permission from the Ethics Committee of İstanbul Provincial Directorate of Health, Mehmet Akif Ersoy Chest and Cardiovascular Diseases Hospital (decision no: 59, date: 10/9/2019). 
Informed Consent: Because the study is retrospective study, patient consent was not obtained.

\section{Authorship Contributions}

Concept: B.B., H.D.Ö., Design: B.B., H.D.Ö., Data Collection or Processing: B.B., Analysis or Interpretation: H.D.Ö., Literature Search: B.B., H.D.Ö., Writing: B.B.

Conflict of Interest: No conflict of interest was declared by the authors.

Financial Disclosure: The authors declared that this study received no financial support.

\section{References}

1. Van Mastrigt GA, Heijmans J, Severens JL, Fransen EJ, Roekaerts P, Voss G, et al. Short stay intensive care after coronary artery bypass surgery: randomized clinical trial on safety and cost-effectiveness. Crit Care Med 2006;34:65-75.

2. De Cocker J, Messaoudi N, Stockman BA, Bossaert LL, Rodrigus IE. Preoperative prediction of intensive care unit stay following cardiac surgery. Eur J Cardiothorac Surg 2011;39:60-67.

3. Almashrafi A, Elmontsri M, Aylin P. Systematic review of factors influencing length of stay in ICU after adult cardiac surgery. BMC Health Serv Res 2016;16:318.

4. Patel PA, Grant BJB. Application of mortality prediction systems to individual intensive care units. Intensive Care Med 1999;25:977982.

5. Saleh HZ, Shaw M, Al-Rawi O, Yates J, Pullan DM, Chalmers JA, et al. Outcomes and predictors of prolonged ventilation in patients undergoing elective coronary surgery. Interact Cardiovasc Thorac Surg 2012;15:51-56.

6. Hulzebos EH, Van Meeteren NL, De Bie RA, Dagnelie PC, Helders PJ. Prediction of postoperative pulmonary complications on the basis of preoperative risk factors in patients who had undergone coronary artery bypass graft surgery. Phys Ther 2003;83:8-16.

7. Bolcal C, Iyem H, Sargin M, Mataraci I, Sahin MA, Temizkan V, et al. Gastrointestinal complications after cardiopulmonary bypass: Sixteen years of experience. Can J Gastroenterol 2005;19:613-617.

8. Aygencel G, Türkoğlu M. Characteristics, outcomes and cost of prolonged stay ICU patients. Yoğun Bakım Derg 2011;3:53-58.

9. Martini V, Lederer AK, Laessle C, Makowiec F, Utzolino S, FichtnerFeigl S, et al. Clinical Characteristics and Outcomes of Surgical Patients with Intensive Care Unit Lengths of Stay of 90 Days and Greater. Crit Care Res Pract 2017;2017:9852017.

10. Ursavas A, Ege E, Yüksel EG, Atabey M, Coşkun F, Yıldız F, et al. Solunumsal yoğun bakım ünitesinde mortaliteyi etkileyen faktörlerin değerlendirilmesi. Yoğun Bakım Dergisi 2006;6:43-48.

11. Yaşlı nüfus sayımı, Türkiye İstatistik Kurumu verileri, 2016. Erişim adresi: http://www.tuik.gov.tr/PreHaberBultenleri.do?id=24644.

12. Naughton C, Feneck RO. The impact of age on 6-month survival in patients with cardiovascular risk factors undergoing elective noncardiac surgery. Int J Clin Pract 2007;61:768-776.

13. Banck M, Walther S, Karlstrom G, Nolin T, Sjöberg F, Samuelsson C. [There are more male than female patients within intensive care. But it is still unclear whether there are gender inequalities in Swedish intensive care or not]. Lakartidningen 2014;111:388-390.

14. Oprea AD, Del Rio JM, Cooter M, Green CL, Karhausen JA, Nailer $\mathrm{P}$, et al. Pre- and postoperative anemia, acute kidney injury, and mortality after coronary artery baypas grafting surgery: a retrospective observational study. Canadian J Anesth 2018;65:4659.

15. Siregar S, Groenwold RHH, de Mol BAJM, Speekenbrink RGH, Versteegh MIM, Bruinsma GJBB, et al. Evaluation of cardiac surgery mortality rates: 30-day mortality or longer follow-up? Europ J Cardio-Thoracic Surg 2013;44:875-883.

16. Doerr F, Badreldin AM, Heldwein MB, Bossert T, Richter M, Lehmann T, et al. A comparative study of four intensive care outcome prediction models in cardiac surgery patients. J Cardiothorac Surg 2011;6:1-8.

17. Argyriou G, Vrettou C, Filippatos G, Sainis G, Nanas S, Routsi C. Comparative evaluation of Acute Physiology and Chronic Health Evaluation II and Sequential Organ Failure Assessment scoring systems in patients admitted to the cardiac intensive care unit. J Crit Care 2015;30:752-757.

18. Kamış A, İşçimen R, Kelebek Girgin N, Yavaşcaoğlu B, Kaya FN, Kahveci F, et al. Yoğun bakım hastalarında mikroalbuminürinin prognostik değeri. Uludağ Üniversitesi Tıp Fakültesi Dergisi 2008;34:107-114.

19. Marik PE, Varon J. Severity scoring and outcome assessment. Computerized predictive models and scoring systems. Crit Care Clin 1999;15:633-646.

20. Rady MY, Ryan T, Starr NJ. Perioperative determinants of morbidity and mortality in elderly patients undergoing cardiac surgery. Crit Care Med 1998;26:225-235.

21. Weiss YG, Merin G, Koganov E, Ribo A, Oppenheim-Eden A, Medalion B, et al. Postcardiopulmonary bypass hypoxemia: a prospective study on incidence, risk factors, and clinical significance. J Cardiothorac Vasc Anesth 2000;14:506-513.

22. Higgins TL, Estafanous FG, Loop FD, Beck GJ, Lee JC, Starr NJ, et al. ICU admission score for predicting morbidity and mortality risk after coronary artery bypass grafting. Ann Thorac Surg 1997;64:1050-1058.

23. Doerr F, Badreldin A, Heldwein M, Bossert T, Richter M, Lehmann $\mathrm{T}$, et al. A comparative study of four intensive care outcome prediction models in cardiac surgery patients. J Cardiothorac Surg 2011;6:1-8.

24. Amann K, Tyralla K, Gross ML, Eifert T, Adamczak M, Ritz E. Special characteristics of atherosclerosis in chronic renal failure. Clin Nephrol 2003;60:S13-21.

25. Ko W, Kreiger KH, İsom OW. Cardiopulmonary bypass procedures in dialysis patients. Ann Thorac Surg 1993;55:677-684.

26. Bhattacharyya N, Cheung AH, Dang CR, Wong LL, Myers SA, Ng $\mathrm{RC}$, et al. Open heart surgery in patients with end-stage renal disease. Am J Nephrol 1997;17:435.

27. Pappas S, Maragoudakis P, Vlastarakos P, Assimakopoulos D, Mandrali T, Kandilotos D, et al. Surgical versus percutaneous tracheostomy: an evidence-based approach. Eur Arch Otorhinolaryngol 2011;268:323-330.

28. Düger C, İsbir AC, Uysal İÖ, Kol İÖ, Kaygusuz K, Gürsoy S, et al. The evaluation of the complications of surgical and percutaneous tracheostomies in intensive care unit. Turk J Anaesthesiol Reanim 2013;41:84-87. 
29. Ak K. Perkütan Trakeostomi. Tıp Araştırmaları Dergisi 2016:14:6773.

30. Totoz T, Türk HŞ, Sayın P, Ünsal O, Çınar S, Oba S. Yoğun bakım ünitemizdeki (YBÜ) perkütan trakeotomi pratiğimiz. Ş.E.E.A.H. Tıp Bülteni 2013;47:11-15.

31. Öncül S, Yılmaz M, Gaygusuz EA, Oysu DA, Esen O, Şimşek T, et al. Our experience in percutaneous tracheostomy which performed by Griggs method: 38 cases. Medical Journal of Kocaeli 2014;2:1-4.
32. Ersoy A, Ali A, Ünlü N, Kara D, Turgut N. Griggs Yöntemi ile Gerçekleştirilen 53 Perkütan Trakeostomi. Okmeydanı Tıp Dergisi 2012;28:134-137.

33. Canver CC, ChandaJ. Intraoperativeand postoperative risk factorsfor respiratory failure after coronary bypass. Ann Thorac Surg 2003;75:853-857; discussion 857-858. 